\title{
BAHRÎ MEMLÛK HÜKÜMDARLARININ EĞLENCE VE ALIŞKANLIK UNSURU OLARAK ŞARAP
}

Dr. Arş. Gör.Tulay YÜREKLi ${ }^{\star}$

\section{ÖZ}

Orta Çağ Türk-isslâm devlet adamlarının eğlence meclislerinde, sofralarında alkollü içeceklerin özel ve önemli bir yeri olmuştur. Türkler farklı gıda maddelerinden çeşitli içkiler imal etmiş̧ir. Alkollü içecekler arasında en çok şarap tercih edilmiştir. Şarabın geleneksel bir hüviyet kazanmasında eski İran geleneği etkili olmuştur. Gazneliler, Büyük Selçuklular, Zengiler ve Eyyûbiler bu geleneğin temsilciliğini üstlenmiştir. Ancak, İslâm'ın alkolü tahrim kaidesine bağlı kalanların tutumu bu geleneği dönem dönem kesintiye uğratmıştır. Bahrî Memlûk hükümdarları da bu konuda dönemin temayülüne uygun hareket etmiş, şaraba öncelik vermiştir. Bununla birlikte, kımız içme alışkanlıklarını da devam ettirmişlerdir. Söz konusu dönemde, alkol serbestisi ve yasağı, genellikle Memlûk hükümdarlarının bu hususla ilgili dinî yasağa sadakatleriyle paralel gitmiştir. Yasaklara, ağır cezalara rağmen, alkol tüketimi tamamen engellenememiştir.

Kahire'de şarap üretiminin merkezleri Hıristiyan yerleşim yerleridir. Bunların başında, günümüzde Kahire'nin halkın çoğunluğunu Hıristiyanların teşkil ettiği semtlerinden Şubra ve enNasır Muhammed zamanında esirlerin meskeni haline dönüştürülen Hızanatu'lbunûd gelmektedir. Şarabın yasak kılındığı dönemlerde bile, Müslüman-Hıristiyan ahali arasında yaşanan sıkıntılı dönemler ve birkaç devlet adamının alkol karşıtı şahsi girişimleri hariç, gayrı Müslimlerin şarap üretimi ve tüketimi kısıtlanmamıştır.

Şarap imali ve ticareti, devlete mühim gelir sağlamıştır. İskenderiye şarap ticaretinin kilit noktasıdır. En-Nâsır Muhammed'in oğlu Melikü's-sâlihlmâdeddinEbû İsmail'in saltanat nâibi emir el-HâcÂl Melik'in şarap ticaretini yasaklaması, şehrin ekonomisini bozmuştur.

Anahtar Kelimeler: Bahrî Memlûk, Büyük Selçuklu, Zengiler, Eyyûbîler, Şarap

\section{WINE AS AN ELEMENT OF ENTERTAINMENT AND HABIT OF BAHRI MAMLUK}

\section{RULERS}

\section{ABSTRACT}

Alcoholic beverages have a special and important place in the entertain mentas semblies and tables of medieval Turkish-Islamic statesmen. Turks made various alcoholic drinks from different food stuffs. Among the alcoholic beverages wine the most preferred. The ancient Iranian tradition has been instrumental in making wine a traditional identity. Ghaznavids, Great Seljuks, Zengid sand Ayyubids assumed there presentatives of this tradition. However, this tradition was interrupted from time to time due to the attitude of those who remained tied to the base of Islam that forbids alcohol. The rulers of Bahrî Mamlûk also acted in accordance with the tendency of the period and gave priority towine. However, they have also maintained the habit of kımız. In the period the free domand prohibition of alcohol generally came in linewiththeloyalty of the Mamluk rulers to the religious ban on this matter. Despite the prohibitions and heavy penalties, alcohol consumption has not been completely prevented.

*Adnan Menderes Üniversitesi Fen Edebiyat Fakültesi Tarih Bölümü, tulayyurekli@yahoo.com, Orcid Id: 0000-0002-9264-9207 
The centers of wine production in Cairoare Christian settlements. Shubra, where the majority of the population is Christians and Hizanatu'lbunûd, which was converted into there sidence of the prisoners during the time of en-Nâsır Muhammad, are the most famous among the secenters.

Even during the times when wine was banned, the production and consumption of nonMuslims was not restricted, except forthet roubling periods between the Muslim-Christian community and the personal attempts by a few statesmen against alcohol.

The wine production and trade provided significant income to the state. Alexandria was the key point in the wine trade. Because of the fact that Emir al-HâcÂl Melik who is naib alsaltana of en-Nasir Muhammad's son Meliku's-sâlihlmâdeddin Abu İsmail banned the wine trade, the economy of thecity broke.

Keywords: Bahrî Mamlûks, Great Seljuks, Zengids, Ayyubids, Wine.

\section{Gíriş}

Alkollü içki yapımı ve tüketimi neredeyse insanlık tarihi kadar eskidir. Alkollü içecekler dinsel âyinlerin, geleneksel törenlerin, eğlence meclislerinin önemli unsurlarından biri olup bu işlevini günümüze kadar sürdürmüştür. Alkollü içecek türleri, bu içeceklere yüklenen anlamlar, tüketimi ile ilgili pratikler toplumdan topluma değişiklik göstermiştir. Bu farklılığın temel nedeni, genel manada, din ve kültürdür. Bu bağlamda Türklerin alkollü içeceklerle ilişkisini de bu iki ana nokta belirlemiştir. İslâm öncesi Türk kültüründe alkollü içeceklere ilişkin bir kısıtlama yoktu. Türkler erken devirlerden itibaren bu türden içecekleri üretip tüketiyorlardı. Oğuz Destanı'nda Oğuz- Han'ın doğumunun anlatılı̆̆ı bölümde günümüz Türkçesiyle "Pişmemiş etler ister, aş, yemek ister oldu! Etraftan şarap ister, eğlenmek ister oldu! (Ögel 1983:I:113;Kılıç ve Albayrak 2012: 709) ifadesi bunu açıkça göstermektedir.

Eski Türklerde içki, tüketilme sebebine bağlı olarak farklı anlamlar intiva etmiştir. Hakanların "en ince ayrıntılarına kadar düzenlenmiş içki âlemleri" hakanın nüfuz ve ününü yükselten bir tür âyîn hükmünde idi (İnalcık 2016: 73). Çeşitli törenler, kabuller sırasında ikram edilen içkiler, barışın, bağın, anlaşmanın, konukseverliğin göstergesi sayılmaktaydı. Nitekim, Kök Türk hükümdarı Tung Yabgu ile, 629'da, Isıkgöl yakınında Suyab (Balasagun) şehrinde karşılaşan Budist HuenCang, bölgede darı ve üzüm ziraatının yapıldığını, elçilerin kabulünde içkilerin verildiğini ve Han'ın sofrasında yiyeceklerin ve şarabın bulunduğunu kaydetmektedir (Turan 1969: 384).

\section{Bahrî Memlûkler Dönemine Kadar Şarap}

\subsection{Gazneli, Karahanlı ve Büyük Selçuklu Hükümdarları ve Şarap}

Köymen, Kaşgarlı Mahmud'un Divanına dayanarak Büyük Selçuklu çağında Türklerde içki meselesini ele almış ve değerlendirmiştir. Bu değerlendirmelere göre Türklerin alkol içeren başlıca içecekleri, milli içki olarak telakki edilen "kımız" dedikleri mayalanmış kısrak sütü idi. Kımızın yanı sıra daha çok Çinliler tarafından üretilen "pirinç rakısı", darıdan "buhsum", buğdaydan "buğday içkisi", farklı maddelerden şarap ( Köymen 2001: III: 432-434), ayrandan "ayran arağası" (Ögel 1978: V:29) elde ederler ve tüketirlerdi. Türkler İslâm dairesine girdikten sonra, ilerleyen zaman içinde kımızın yerini yavaş yavaş şarap aldı. Türkler şaraba "bor", "çağır", "sücik (süçük)", "kızıl sücik (süçük)" diyordu (Bozkurt: 2000: XX: 456). Bununla birlikte asıl şarap, "süçik (süçük)" ve İli havzası Türklerinin ise renginden ötürü "kızıl süçük" dedikleri şaraptı. Şarap 
yapıldıktan sonra soğutulur, tulumlarda veya söbü kaplarda saklanırdı. Türkler arasında, şarap tulumuna "tim" meyhaneciye "timci" denirdi (Köymen 2001: III: 432434). Şarabın kıymetlisi, yüksek yerlerde yetiştirilen siyah üzümden elde edilen ve lezzetinin artması için bekletilendi. (Dede Korkut Kitabı:116, 128). Türk algısına göre şarap, sarhoşluk veren, gönülleri ferahlatan bir araçtı; "arı gönülde pas tutsa şarap açardı."(Dede Korkut Kitabı:167).

İnalcık, Türk devlet ricalinin şarap içme geleneğine dikkat çekerek, mevzuyu eski İran geleneğinin tesiriyle açıklamaktadır. İnalcık'a göre, bu geleneğin temsilcisi İranlı bürokratların devlet bünyesinde ağırlığı ve eski İran topraklarına hükmedilmesi, Türk devlet ricalinin işret (içki-şarap ve sohbet) meclisini tesiri altına almış ve bu gelenek farklı Türk-İslâm hanedanlıkları tarafından asırlar boyu sürdürülmüştür. Orta Çağ Türk-İslâm hükümdarlarının, her zaman hazır bulunan işret meclislerinin olmazsa olmazları, eski Sâsânî geleneğinden gelen musiki, şiir ve şaraptı (İnalcık 2016: 8-9). Şarap meclislerinin edebe ilişkin bir takım kaideleri vardı. Nizâmülmülk bu kuralları Siyasetnâmesinde ayrı bir fasıla açarak kaydetmektedir. Bu kurallara göre, işret meclisi kurulduğu vakit kimlerin çağrılacağı önceden belirlenirdi. Özel işret meclisine gelmeye izin verilenlerin yanlarında, bir köle hariç, sâkî veya sürahi getirmeleri katiyyen yasaktı (Nizâmulmulk 2009: 141).

Orta Çağ Türk-İslâm hükümdarlarının bu geleneğin tesiri altında ne ölçüde şarap veya içki tükettiklerini tespit etmek mümkündür. Bu noktada İranî geleneğin temsilcisi Sâmânîlerin halefleri Gazneli devlet ricalinden başlamak yerinde olacaktır. Devletin kurucusu Sâmânî sarayında yetişen Alptekin ve Sebüktekin'in şarap meclisleri mevcuttu (Nizâmulmulk 2009: 153). Sultan GazneliMahmud'un da meclisinde şarap eksik olmazdı (Nizâmulmulk 2009: 50 vd). Melik Mesud da, içki ve eğlenceyle meşgul olurdu (Bundârî 1999: LX).

Şarap içme geleneği Büyük Selçuklulara da sirayet etti. Tacüddevle Tutuş, kendini kaybedecek kadar şarap içerdi (İbnü'l Adîm 1982: 18). Kavurt da, "gece gündüz şarap içerdi öyle ki bu sebepten ötürü adı sanı kalmamıştı” (İbnü’l Esîr 1987: XI: 6566).Kirman Selçuklularından Turan-şah'dan sonra gelen Iranşahiçkiye, sefahate düşkündü (Turan 1969: 207). Selçuklu hükümdarları arasında dindar kişiliğiyle bilinen sultan Sancar da önceleri şarap içerken (Bundârî 1999: 241, 247), tövbe etmiş ve sarhoşluk verici maddeleri ülkesinde yasaklamıştı. Sultan, Hıristiyan tebanın çok az olduğu İran'da dahi bunların tüketilmesini men etmişti. İran'da onun verdiği bir intisap menşûrunda muhtesibin görevleri sayıldıktan sonra, "fesâd ehlinin cezalandırılması, camiler ve mezarlıklar civarında içki ve fıskın menedilmesini, zimmileri tezlil eden kıyafetlerine (gıyâr) dikkat gösterilmesi, kadınların ilim ve vaaz meclisterinde erkeklerle karışık oturmaması" (Turan 1958: 36) hususları kesin hatlarla çizilmişti. Büyük Selçuklu ailesinin kadın üyelerinin bu türden alışkanlıklar edinmedikleri muhakkaktır. Bununla birlikte Bundârî, Berkyaruk'un annesinin candar Gümüştekin'le yakınlaştığını ve birlikte şarap içerek vakit geçirdiklerini (Bundârî 1999: 85) yazmaktadır.

\subsection{Zengiler ve Eyyûbîlerde Şarap}

Büyük Selçukluların Orta Doğu'daki uzantılarının alkollü içeceklerle ilişkisi, dinî yasağa bağlılıkları nispetinde seyretmiştir. Artuklulardanilgazi şarabı pek severdi; "şarap içmeye başladığında sarhoşluğu yirmi gün geçmezdi" (UsâmelibnMunkız 
2006:192). Zengiler Devleti'nin kurucusu AtabegZengi de şaraptan keyif alırdı (Bundârî 1999:188). Oğlu Atabeg Nureddin Mahmud, çok koyu bir dindar olduğu için, ordugâhında müzik ve samâ'a müsamaha göstermez ve şarap içmeğe müsaade etmezdi. Sürekli Kur'an okutur ve dinlerdi (İbnü'l Esîr 1987: XI: 322-324). Atabeg Nureddin Mahmud'un oğlu el-Melikü's-Salih de tıpkı babası gibi bu yasağa riayet etti. Hastalandığı sırada tabipler şarap içmesini tavsiye edince bu hususta din âlimlerinden cevaz almasına rağmen "Allah'a bana haram kıldığı şeyle kavuşmam" diyerek içmeyi reddetmişti (İbnü'l Esîr 1987: XI: 376-377). Zengiler döneminde Musul merkezde içki satan dükkânlar mevcuttu. Nureddin Mahmud tarafından bölgede şarap üretimi ve tüketimi tamamıyla yasaklandı ise de ölümünün ardından Seyfeddin Gazi b. Mevdud bu yasağı lağvederek şarabın üretilmesine ve tüketilmesine tekrar izin verdi. Fakat, halk 575/1179-1180 yılında şiddetli kuraklık sebebiyle yağmur duasına çıktığında alayın içinde bulunan Seyfeddin'e yalvararak içki satışına mani olmasını isteyince Seyfeddin bu isteği kabul etmiş ve bunun üzerine halk şehirde içki satılan evleri yağmalamıştı (İbnü'l Esîr 1987: XI: 359).

Eyyûbî devletinin kurucusu Selahaddin Eyyûbî her ne kadar önceleri şarap içse de tövbe ederek (Gürbüz 2012: 47) tıpkı Nureddin Mahmud b. Zengi gibi haram olan şeylere izin vermedi. Mısır'da yönetimine geçince "mizr" (bir tür bira) denilen alkollü içecek üzerinden alınan vergiyi geçersiz kıldı ve mizri yasakladı (Makrîzî 1998: I: 298). 590/1193-1194'de Selahaddin'in oğlu Mısır hâkimi el-Melikü'l Aziz Osman döneminde, ülkede yaşanan ekonomik krizden ötürü bu yasak kaldırıldı, haşiş öğütmek için bir değirmen kuruldu, şarapla dolu testiler açıkça insanların gözü önünde çarşılara taşındı, mizr imalatının yapıldığı buyût el-mizr korundu ve üzerine günlük 16 dinarlık ağır vergi konuldu. İki yıl sonra bu vergiler arttırılarak 12 bin dinara çıkarıldı. Fakat Ramazan ayında üzüm sıkımı arttığı için üzüm pahalandı ve şarap üretimi azaldı (Makrîzî 1998: ı: 303; II: 376; Lewicka 2004: 60-61, 77). El-Aziz'in kendisi de şaraba müptela idi. İbnü'IEsîr'in kaydına göre, Dımaşk'ı kardeşi el-Efdal'den aldıktan (27 Recep 592/26 Haziran 1196) hemen sonra el-Efdal'e geri verecek kadar sarhoş olmuştu. (İbnü'l-Esîr 1987: XIl:104-106). El-Melikü'l-Efdal de el-Aziz gibi şaraba pek düşkündü. Şarap içmekten, şarkı dinlemekten zevk alırdı. Dımaşk'ageldiginde (3 Ağustos 1194) bütün vaktini şarap ve şarkıyla geçiriyordu. Sonra bir gün bir anda tövbe ederek içkiyi terketmişti (İbnVâsıl 1960: III: 40; Şeşen 2004: XIX: 62). DımaşkEyyûbî hükümdarı Melikü'l Muazzam İsa b. I. Melik el-Âdil (ö. 624/1227) de içki konusunda sınır tanımıyordu. Sultan Mardinli meşhur tıp alimi İsmail b. İbrahim'den (ö. 637/1240) hurma şarabına fetva vermesini isteyecek kadar ileri gitmişti. Neyse ki İsmail b. İbrahim, bu isteği reddetmişti (Turan 1973: 223). Melikü'l-Eşref Muzafferüddin Musa b. I.el-Meliki'lÂdil Muhammed b. Eyyûb (ö. 635/1237) da son derece dindar bir hükümdar olmasına rağmen içkiye bağımlıydı (Kaya 2004: XIX: 65). Sultan II. Melik el-Âdil (ö.12 Şevval 645/9 Şubat 1248) de eğlenceye dalıyor, şarap içmekten adeta bitkin düşüyordu (Makrîzî 1936: I/II: 269). HısnıKeyfa hâkimi, Necmeddin Eyyûb'un oğlu Turanşah da, kendisini içkiye, eğlenceye veriyor, sarhoş olunca ağlıyor, üzerindeki elbiseleri yırtıyor, Bahrî Memlûklerine hakaret edip köklerini kazıyacağını söylüyordu (Şeşen 2016:15). Meyyafarikin hâkimi II. el-Melikü'l Kâmil (642-658/1244-1260) ise, son derece dindar olup ülkesinde şarabı/içkiyi tamamen yasaklamıştı (Cahen 1953: 102).

Makrîzî, 644/1246-1247 senesinde el-Melikü's-Sâlihìmadüddin İsmail b. I.elMeliki'l-Âdil Muhammed b. Eyyûb'un (ö. 648/1251) Harezmli kuvvetlerle iş birliği 
yaparak Dımaşk kuşatmasından söz ederken şehirde müthiş bir pahalııı, kıtlık ve veba yaşanmasına rağmen şarap ve fıskın insanlar arasında tükenmediğini (Makrîzî 1936: I/II: 322) belirtir. Makrîzî'yi hayıflandıran bu kayıt, Eyyûbilerin son dönemlerinde, Dımaşk'ta alkol tüketiminde epeyce bir artışın olduğuna işaret etmektedir.

\section{Bahrî Memlûk Hükümdarlarının Eğlence ve Alışkanlık Unsuru Olarak} Şarap

Memlûk hükümdarları Türkistan'da edindikleri kımız içme geleneğini Mısır'a taşımıştır. Bunun yanı sıra şarap ta popülaritesini korumuştur. Memlûk devlet adamları, alkollü içeceklerin, dönem dönem içilmesi ve satılmasına izin vermiştir. Memlûk hükümdarlarının alkollü içecek alışkanlıkları, alkollü içki tüketimine gösterdikleri müsamaha ve bunun derecesi, alkole getirilen yasaklar, Memlûk dönemi tarihçileri tarafından kaydedilmiştir. Çalışmamızda temel kaynak olarak dayandığımız Makrîzî̀nin es-Sulûk'u, yukarıda belirtilen hususların tespitinde bilgi vermektedir.

Arapça kaynaklarda şarap ve diğer alkollü içkileri ifade etmek için çoğunlukla "hamr" kelimesi kullanılmıştır. Metin akışından kelimenin Türkçe karşılığını kestirmek mümkün olsa da kimi yerlerde bu imkansızdır. Bu sebeple, muhtemel bir karışıklığın önüne geçmek için hamr kelimesi ile Türkçe karşılığını yan yana vermeyi uygun bulduk.

Memlûkler döneminde şarap üretimi çoğunlukla Hıristiyan ahalinin elindeydi. Şarap ticareti ve şarap üreticilerinden alınan vergi (cihedü'l-müfrede) yıllık bin dinar olup memâliku's-sultaniyyenin (kapıkulu birlikleri) yem, kisve ve maaşlarını karşılayan divanu'l-müfrede'ye aktarılırdı (Makrîzî 1936: I/II: 373).

Memlûk hükümdarları arasında içkiyi/hamr ilk yasaklayan Memlûk hükümdarı Şeceretuddur'un kocası el-Melikü'IMuiz İzzeddin Aybek'dir. Aybek, es-Salihiyye'deki medreselerde mezalim oturumu düzenlemiş ve hemen akabinde şarap/hamr ve cihetu'Imüfrede'yi yasaklamıştı (20 Şaban 648/ 17 Kasım 1250) (Makrîzî 1936: I/II: 373). Bu uygulama Aybek'in ölümünden sonra kalkmış görünmektedir. Aybek'in oğlu Ali'nin yaklaşık iki yıllık hâkimiyet döneminde bu yasağın ilga edildiğine dair bir kayıt bulunmamaktadır. Ali'nin yerine geçen Sultan Kutuz'un (ö. 658/1260) şaraptan sakınıyor (Aynî 2010: I: 260) olması bu yasağın devam etmiş olabileceği düşüncesini uyandırmaktadır. Fakat,Kutuz'un yerini alan Rükneddin Baybars'ın devlete büyük bir gelir getirmesine rağmen alkolü ülkede men etmesi ve çok kere bu yasağı yenilemesi, Aybek'ten sonra bu yasağın hükümsüz kılındığı ihtimalini güçlendirmektedir. Rükneddin Baybars Bundukdârî çok samimi bir Müslüman idi; gerek sıradan bir birey ve gerek hükümdar olarak, Şeriat hükümlerine çok dikkat ederdi (Köprülü 2001: II: 360). Bu sebeple, toplum ahlakına mugayir fiiliyatları önlemek amacıyla bir dizi tedbir getirdi. 662/1263-1264 yılında Şam'da iken Kahire'ye saltanat naibine büyût el-mizr'ı (bira yapılan yerler) kaldırdığını ve vergisini geçersiz kıldığını yazdı (Makrîzî 1998: I: 304). 664/1266 senesi Ramazan Bayramı'nda "kimsenin içki içmemesini ya da bulundurmamasını aksi takdirde asılacaklarını" ilan etti (Makrîzî 1936: I/II: 546). 24 Zilhicce 664/26 Eylül 1266 'da Dımaşk'ta iken içkiyi yasakladı, ülkenin tamamında oyun ve eğlence mekanlarını kapattı (Makrîzî 1936: I/II: 553). 665/1266-1267'da haşiş vergisinin, şarabın, munkiratın, müskirat evlerinin, meyhanelerin ve günahların Mısır'dan silinmesini emretti (Makrîzî 1998:I: 305). 666/1267-1268 yılında Trablus'danHımıs'a indiğinde içkinin ve munkiratın yasaklanması emrini verdi (Makrîzî 
1936: I/II: 566). 9 Cemaziyelahir 666/ 25 Şubat 1268'de şarabın dökülmesini emretti, fuhuşu yasakladı ve fuhuş üzerinden alınan vergiyi kaldırdı (Makrîzî 1998: I: 305). 667/1268-1269'da "genelde fesad ehlinin oturduğu hanlar" yağmalandı, fesada yol açan kadınların tamamı tutuklanıp evleninceye kadar hapiste tutuldu. Fesada sebep olan erkekler ise sürüldü. Sultan ayrıca böyle yerlerden alınan vergiyi iptal etti ve ikta sahiplerine helal vergilerden gelir verdi (Makrîzî 1936: I/II: 578). 27 Zilhicce 669/6 Ağustos 1271 'de şarap ve vergisini yasakladı ki bu vergi günde 100, senede 1000 dinara ulaşıyordu (Makrîzî 1936: I/II: 595; 1998: I: 305). Alınan önlemlere, konulan yasaklara rağmen içki tüketimi aralıklarla gizli bir şekilde devam etti. Fakat sultan bu konuda tavizsizdi. Yasağı çiğneyenin cezası ölümdü. Nitekim 12 Recep 674/1 Ocak 1276'da Sadru'lbâz olarak bilinen tavaşiŞucaeddinAnber'işarab içtiğinden dolayı Kal'atu'l-cebel'in altında astırdı (Makrîzî 1936: I/II: 624). Burada değinmek gerekir ki Baybars'ın, emirlerinin ve memlûklerin başlıca içeceği kımız olup alkollü içecek sınıfında değerlendirilmiyordu. Nitekim Sultan Rebiülâhir 671/Ekim-Kasım 1272'de bir süre Dımaşk'ta kaldıktan sonra Mısır'a dönünce kımız içmek için güzel bir meclis düzenlemiş, aksakallılar, emirler ve ileri gelen nedimler bu meclise katılmış, Bire'de Moğolları nasıl yendiklerini andıktan sonra kımızlarını fon dip yapmışlardı (Baybars elMansurî 2016:67-68). Yine Bire'den döndükten sonra, emirlerinden İzzeddin Dimyatî̀yi serbest bırakmış, onunla ve büyük emirlerle birlikte kımız içmişti (Makrîzî 1936: I/II: 697). Sultan ölmeden hemen önce de, kımız içmiş, böylelikle, "sevinci ve mutluluğu artmıştı"(Makrîzî 1936:I/II: 635).

El-Mansûr Seyfeddin Kalavun, Şevval 678/Şubat-Mart 1280'de birkaç günlüğüne şarabı serbest bıraktıktan hemen sonra şarapların dökülmesini emrederek şarap ve şarhoşluk veren her şeyi yasakladı (Makrîzî 1939: I/III: 668). El-Melikü'l-Eşref Selahaddin Halil b. Kalavun el-Elfî es-Salihi (ö. 693/1293) döneminde içkiye yeniden izin çıktı. Sultan Ramazan ayında dahi şarap içiyordu. Fakat daha sonra bu alışkanlığından vazgeçip içki ve afyonu yasakladı (Özaydın:1997: XV: 320). Sultan Laçin gençliğinde Dımaşk'ta ayanlarla içki ve eğlence meclisleri düzenlerdi. Eğlencede ve içkide aşırıya kaçınca, vezir Sencer eş-Şucâî, Kalavun'a durumu bildirmiş, bunun üzerine Kalavun, saltanat naibi Emir Toruntay'ın ağzıyla Laçin'i uyarıp tehdit etmişti. Laçin, saltanata geçince içki/hamr ve dine aykırı diğer işlerden vaz geçti (Makrîzî 1939: I/III: 861). En-Nâsır Nâsıreddin Muhammed b. Kalavun, içkiden nefret eder, emirlerinden içenleri kendisinden uzaklaştırırdı (Makrîzî 1942: II/II: 534). Bununla birlikte en-Nasır Muhammed b. Kalavun'un ikinci saltanatı döneminin ilk yıllarında Kahire'de içki/hamr tüketimi ve fuhuşta bir artış yaşandı. Bu duruma dikkat çeken Makrîzî 702/1302-1303 senesinde bütün Mısır'da vuku bulan, Kahire ve diğer yerleri etkileyen şiddetli büyük depremle ilgili havadislere giriş yaparken, depreme sebep olarak vasfı mümkün olmayacak derecede çok içki içilmesini ve fuhuşu ortaya sürmektedir (Makrîzî 1939: I/III: 942). En-Nasır Muhammed b. Kalavun'un ikinci saltanatı döneminde sultan üzerinde güçlü bir nüfuzu bulunan üstâdüddârı Emir Baybars el-Çaşnigir, sufilerin etkisi ve teşvikiyle gayri Müslim unsurlara karşı sert bir tavır takındı (Kopraman 1992: V: 224). 702/1302-1303 yılında Mısır'da Hıristiyanların Şehid Bayramı'nı, yaşanan karışıklık ve ölümler nedeniyle yasakladı. Bu yasak, şarap ticaretine ve bunun üzerinden devlete aktarılan vergiye de sekte vurdu. Bu bayramda Hıristiyanlar Şubra'da toplanıyor, günlük 100 bin gümüş dirhemlik şarap satıyordu. Bir Hıristiyan bir günde 12 bin gümüş dirhemlik, senede de 120 bin dirhemlik şarap satışı 
yapıyordu (Makrîzî 1939: I/III: 941-942; 1998: I: 199-200). Baybars el-Çaşnigir bununla yetinmeyip emir Salar ile birlikte dine aykırı diğer fiiliyatlarınönünü almak için bir takım girişimlerde bulundu. 706/1306-1307'de, el-Hâkimi diye bilinen ve Kahire'nin dışında bulunan haliçten, kadınlarla erkeklerin birlikte içki içtikleri ve karışıklığa sebep oldukları gerekçesiyle gemilerin geçmesine izin vermediler (Makrîzî 1941: II/l: 29). Baybars elÇaşnigir tahta geçince, 709/1309-1310'da Dımaşk'a, Şam sahillerinde alınan şarap vergisinin iptal edildiğini, şarabın yasaklandığını bildirdi (Makrîzî 1941: II/l: 52). Aynı yıl Mısır'da da aynısını gerçekleştirmek istedi. Bunun için Burci emirlerden Seyfeddin Şeyha'yi görevlendirdi. Emir Seyfeddin derhal işe koyuldu. Kahire valisinden, valinin iki komutanından ve bekçilerden meyhaneleri sordu soruşturdu fakat cevap alamadı. Nihayetinde sıkı bir tahkikat yaptı; içki/hamr içen emirlerin, tüccarların ve katiplerin olduğu bir liste hazırladı, meyhaneleri tespit etti; meyhaneler yıkıldı, şarap imalatçısı Yahudi ve Hıristiyanların evleri yerle bir edildi, şarap içtiği bilinen emirlerin evleri tahrip edildi (Makrîzî 1941: II/l: 53-54).

En-Nâsır Muhammed b. Kalavun III. saltanatı döneminde alkol ve toplumun ahlakını bozacak diğer davranışlara karşı mücadele devam etti. Sultan 709/13091310 'da bu iş için 32 emir görevlendirdi. Bunlar Kahire bölgesindeki meyhaneleri, sûku'l-hayl'ı yaktılar, şarkıcıları ve eğlence erbabını pek çok yerde vurdular (Makrîzî 1941: II/l: 77). Sultan bununla da yetinmedi ve içki içtiği tespit edilen emirleri ağır cezalara çarptırdı. Zilkade 717/Ocak Şubat 1318'de emir Akboğa el-Husna şarap içtiği gerekçesiyle yakalandı, dövüldü ve Dımaşk'a bir emirliğe gönderildi. Yine bu sebepten dolayı emirin haznedarı ikiye bölündü, ashabından bir grubun dili kesildi, bir grubun da gözlerine mil çekildi (Makrîzî 1941: II/l: 176). Muharrem 718/Mart-Nisan 1318'de adet olduğu üzere Hicaz'dan gelen kafiledeki mucerridlerin arasında, Sârim Ozbek elCermekî̀nin bazı suçlarla ve şarap içmekle suçladıkları kişiler tutuklanıp İskenderiye'de hapsedildi (Makrîzî 1941: II/l:180). Sultan 721/1321-1322'de de memaliku'ssultaniyyedenKerimüddin el-Kebire isyan edenler arasında şarap içen bir kişiyi ve gulamını sopayla dövdü (Makrîzî 1941: II/l: 229-230). Sultan, Ramazan 738/Mart-Nisan 1338'de de damadı Melik Timur el-Hicazi'ninmemaliku's-sultaniyyeden memlûklerle eğlence erbabını alıp Nil Nehri'nde fuhuş işlediklerini duydu ve aynı gün Melik Timur ve onunla birlikte şarap içen 40 memlûku ve ashabını Şam taraflarına sürdü (Makrîzî 1941: II/Il: 455). Şarap bağımlısı Melik Timur her gün 50 rıtl ( litre) şarap içiyordu (Makrîzî 1958: II/III: 755).

Sultan Muhammed b. Kalavun'un emirlerinden Şam naibi Emir Tengiz de içki yasağı getirip Dımaşk ve amalinde şaraphaneleri kapattı. Buna uymayanları öldürttü (Makrîzî 1941: II/II: 510). Emir Tengiz bu hususta titizdi. Onun nezdinde alkol tüketimi affedilmez bir suç olduğundan 726/1325-1326 yılında Hısn-ı Keyfa'da es-Salih Saladdin'i öldüren (ö. 726) kardeşi el-Melikü'l Adil Muhiddin, Tengiz'e yazdığı mektubunda kardeşini öldürme nedeni olarak şarap içmesini ileri sürüyordu (Makrîzî 1941: II/I: 276-278).

Sultan Muhammed'in III. döneminde alkollü içecek yasağı bütün şiddetiyle sürdü. Devletin üst kademesinde bulunanlar bu yasağın en mühim takipçileri oldular. Ancak, bozuk şahsiyetleri bu önlemlerin tam manasıyla uygulanmasına olanak vermedi. 23 Ramazan 724/13 Eylül 1324'de Kahire valisi Emir Seyfeddin Kadadar şarabı yasakladı (Makrîzî 1941: II/l: 256). Kötülüğü ve halk üzerinde kurduğu baskı 
nedeniyle sevilmeyen Kadadar 728/1327-1328 senesinde bu baskıyı iyice arttırdı; akşam vaktinden sonra sokağa çıkılmamasını, dışarıya çıkanlardan şarap kokusu gelirse tutuklanacaklarını ve sultan vechu'lbahri'de iken bir dükkânın bile açılmayacağı gibi bir takım kurallar koydu (Makrîzî 1941: II/l: 300-301). Kadadar'dan sonra gelen valilerden Nasıruddin Muhammed b. el-Muhsinî gece kılık değiştirip Kahire sokaklarında yürür, müzik sesi duyduğu, şarap kokusu aldığı eve zorla girer ve ev halkının durumuna göre onlardan bir şeyler alırdı. Bir süre sonra Nasıruddin Muhammed'in de eğlenceye daldığı ve şarap içtiği ortaya çıktı. Buna diğer yolsuzlukları da eklenince Nazıru'l has el-Neşû'nun aracılığıyla görevden alınıp mahkûm edildi (2 Şaban 734/8 Nisan 1334 ) (Makrîzî 1941: II/II: 372). Nazru'lhâs el-Neşû da ondan farklı değildi. Kurnaz el-Neşû aç gözlülüğüne yenik düşüyor, daru'lfakihe'ye (meyve evi) Marsafa ve diğer yerlerden gelen üzümleri kendisi için Şubra'ya şarap yapımı için gönderiyordu. Bir süre sonra bu durum fark edilince el-Neşû bu suçlamadan kurtulmak için Şubra'daki yerin Emir Beştak'a ait olduğunu söyledi. Bunun üzerine sultanın emriyle Kahire valisi, Şubra'ya giderek 1202 adet şarap küpünü kırdı (Makrîzî 1941: II/II: 400, 401). Nihayetinde el-Neşû'nun çevirdiği oyunlar ortaya çıktı, kendisi ve akrabaları tutuklandı ve malları da müsadere edildi (740/1339-1340). Bu mallar arasında 40 bin büyük küp şarap mevcuttu (Makrîzî 1941: II/II: 482).

Kahire bölgesinde şarap imalatının ana noktaları Hıristiyan yerleşim yerleri idi. Sultan en-Nasır Muhammed döneminde bu yerleşim yerlerinin başında yukarıda sözüne ettiğimiz Şubra ve Hızanatu'l-bunud geliyordu. Bunlardan ikincisi, önceleri şehrin hapishanelerdendi. En-Nasır Muhammed b. KalavunKerek'ten dönünce Ermeni ve diğer esirleri burada iskân etmiş ve onlar için burada evler yaptırmıştı. Süreç içerisinde esirler çoğaldı ve burası eğlence mekânına dönüştü. Esirler sene de 32 bin küp şarap üretiyorlardı. "Emirlerin memlûkleri, ailesini terk eden evli-bekar kadınlar ve genç adamlar buraya sığınıyordu". Emir el-HâcÂl Melik Cevkendar bu durumu sultan en-Nasır Muhammed'e bildirdi ise sultan ondan esirleri rahat bırakmasını istedi (Makrîzî 1942: II/III: 640-641; 1998: II:199). En-Nasır Muhammed'den sonra yerine geçen oğlu el-Melikü's-salihİmadeddin Ebu İsmail döneminde halk Hizanatu'lbunud'daki meyhaneleri yağmaladı, Frenk kadınlara saldırdı ve şarap testilerini kırdı. (27 Safer 743/1 Ağustos 1342) (Makrîzî 1958: II/III: 622). Nihayetinde sultanın saltanat naibi Emir Âl Hac 744/1343-1344'de burayı yıktırdı ve ardından kadınlarla ve oyunlarla ilgili bazı yasaklar getirdi (Makrîzî 1958: II/III: 640-641; 1998: II: 200). Emir el-Hac Âl Melik, Kahire valisinden haram işleri ve içkiyi yasaklamasını, fesad ehlini getirmesini istedi. Bunun üzerine Kahire ve Mısır'da kim bir sarhoşu yanında bir testi şarapla getirirse hilat giydirileceği duyuruldu. Halk Kahire sokaklarında adeta ava çıktı. Halk, emirlerin memlûklerini yakalayıp getiriyordu. Hıristiyan yerleşkesi Şubra'daki evler arandı, şarap içenler tutuklanıp üzerlerine şarap dökülerek teşhir edildi. Satın alınan üzüme de kilo sınırlaması konuldu. Kantarla üzüm alanların tutuklanacağı ilan edildi. Evlerden ve gemilerden bütün şaraplar toplatılı (Makrîzî 1958: II/III: 646; Zengin 2018b: 250). El-Hâc bunlarla kalmayıp Frenklerin İskenderiye'ye şarap taşımalarını yasakladı. Bu tüccarlardan biri yılda yaklaşık 40 bin dinar elde ediyordu. Bu yasak kentin ekonomik durumunu bozdu. Sultan naibini bu işten alı koyuncaya kadar bu uygulama yürürlükte kaldı (Makrîzî 1958: II/III: 647). İskenderiye şarap ticaretinden epey kar elde ediyordu. Örneğin, 740 /1339-1340 yılında Suguru el-İskenderiyye'de 
görevden el çektirilen Baybars el-Camedar el-Rükni senede yalnızca şaraptan 30 bin dinar gibi epeyce yüksek bir meblağ kazanıyordu (Makrîzî 1941: II/II: 487).

Sultan Muhammed'den sonra yerine geçen oğlu el-Melik el-Mansûr Seyfeddin Ebû Bekir (7 Haziran 1341-6 Ağustos 1341), eğlenceye ve şaraba çok düşkündü. Emir Kavsûn ve diğer bazı emirler sırf bu yüzden sultanı tahttan indirdi (Makrîzî 1958: II/II: 567 vd.) Sultan en-Nasır Muhammed'in oğullarından Ahmed (Makrîzî 1958: II/III: 573; Zengin 2018a: 265-266) ve el- Melikü'l Şaban şarap ve eğlencede oldukça ileri gittiler. Şaban, Kahire civarında küçük bir belde olan Seryakus'a (Yakut 1977: III:218) gezintiye çıkar, memaliku's-sultaniyyeden emirlerle içmekten bitkin düşerdi. "Seryakus adeta meyhane olmuştu" (Makrîzî 1958: II/III: 689). Sultanın yalnızca kendisi değil haremindeki kadınlar da içerdi. Haremi gezintiye çıktığında yanlarında 30 bin dirhemlik küp şarap götürürdü (Makrîzî 1958: II/III: 713). Sultan el-Melik en-Nasır Hasan b. Muhammed b. Kalavun kardeşlerinin aksine şaraba el sürmezdi (Makrîzî 1970: III/l: 62).

\section{Sonuç,}

Eski İran işret geleneğinin önemli unsurlarında olan şarap, Orta Çağ'da en çok rağbet gören içki olmuştur. Kimi devlet adamları şaraba müptela iken kimileri de bu türden içeceklerin imaline ve alım-satımına izin vermemiştir. Bunu, temelde, devlet adamlarının bu husustaki dinsel yasağa sadakatleri belirlemiştir.

Bahrî Memlûklerde alkole karşı ciddi yasaklar koyup uygulayan Sultan Baybars el-Bundukdari'dir. Baybars el-Çaşnigir ve en-Nasır Muhammed de ciddi yaptırımlar getirmiştir. Her üç hükümdar döneminde alınan önlemler, denetlemeler ve cezalar toplum düzenini bozan din dışı hal ve hareketlerin sıkı bir şekilde denetlendiğini izah etmektedir. Bütün baskılara, kurallara, cezalara karşın az ya da çok alkol tüketimi gizli saklı sürmüştür.

En-Nasır Muhammed'in oğulları döneminde alkol yasağı rafa kaldırılmıştır.

Bahrî Memlûkler, kımızı Mısır’a taşımıştır. Fakat kımız içimi memlûklerle sınırlı kalmıştır.

İçki üretimi Kahire'de Hıristiyan bölgelerde yoğunlaşmıştır. Bu yerlerin başında Şubra ve Hızanatu'l-bunûd gelmektedir. Hıristiyan ahali içki üretiminde birkaç hadise haricinde serbest bırakılmıştır.

Şarap üretimi ve üzerinden alınan vergi devlete büyük gelir getirmiştir. İskenderiye'nin şarap ticaretinde mühim bir yeri vardır.

\section{KAYNAKLAR}

AYNî, (2010), Ikdu'ICumân, (Asru Selâtini Memâlîk), I, Tahkik: Muhammed MuhammedEmîn, Kahire: Dâru'Ivesâikikaymiyye.

BAYBARS EL-MANSURÎ, (2016), Et-Tuhfetul-Mulûkiyyefi'd-Devleti't-Turkiyye, (Çev:Hüseyin Polat), Ankara: TTK. 
BOZKURT, Nebi, (2000), “İçki”, TDViA, İstanbul: Türk Diyanet Vakfı: C. XXI: s. 455456.

BUNDÂRî (1999), Zubdetu'n-Nusra ve Nuhbetu'l-Usra, Irak ve Horasan Selçukluları Tarihi, (Çev: KıvameddinBurslan), Ankara: TTK.

CAHEN, C., ( 1953), “XIII. Asır Ortalarında Cezire”, Çev: Neşet Çağatay, Ilahiyat Fakultesi Dergisi, C. IV: s. 93-106.

Dede Korkut Kitabı, (Yayınlayan ve Çeviren: Muharrem ERGiN), İstanbul: Boğaziçi Yayınları.

GÜRBÜZ, Osman, (2012), "iktidara Uzanan Yolda Eyyûbî Ailesinin Serüveni”, TAED, S.48: $387-405$.

İBNÜ'L ESÎR (1987), el-Kamil fi't-Tarih, Büyük İslâm Tarihi, XI, (Çev: Abdülkerim Özaydın), İstanbul:Bahar Yayınları.

İBN VÂSIL, (1960), Muferricu'I-Kurûb, III, (Tahkik: CemaleddinŞeyyal), Kahire.

INALCIK, Halil, (2016), Has-Bağçede 'AyşuTarab, İstanbul: İşbankası Yayınları.

KAYA, Önder, (2004), "el-Melikü'l-Eşref, Mûsâ", TDVIA, İstanbul: Türk Diyanet Vakfı: C. XIX: s.65-66.

KILIÇ, Sami, ALBAYRAK, Ali, (2012), “İslamiyetten Önce Türklerde Yiyecek ve İçecekler", TurkishStudies, Volume 7/2 Spring: p.707-716

KOPRAMAN, Kazım Yaşar, (1992), "Baybars II", TDVIA, İstanbul: Türk Diyanet Vakfı, Cilt.V: s. 224.

KÖPRÜLÜ, Fuat, ( 2001), "Baybars I", IA, Eskişehir: ETAM A.Ş. Matbaa Tesisleri: C.II: s.357-363.

KÖYMEN, Mehmet Altay, (2001), Büyük Selçuklu İmparatorluğu Tarihi, III -Alp Arslan ve Zamanı-, Ankara: TTK.

LEWICKA, Paulina B., (2004), "AlcoholanditsConsumption in MedievalCairoTheStory of a Habit", StudiaArabistyczne i Islamistyczne, s.12: 55-97.

MAKRÎZî (1998), El-Mevâizve'I-İtibâr, I, (Tahkik: Muhammed Zeynuhum ve Medîha Eş-Şarkâvî), Kahire:MektebetuMabûla..

MAKRÎZÎ, (1936), Kitâb es-Sulûk, I/II, ( Neşreden: Muhammed Mustafa Ziyade), Kahire: Dâru'lkütub el-Mısrıyye.

(1939), I/III, Kahire: Matbaatu'Icenne.

(1958), II/III, Kahire: Matbaatulcenne.

(1941), II/I-II, Kahire: Matbaatulcenne.

(1970), III/I, (Tahkik Saîd Abdulfettah ‘Âşûr), Kahire: MatbaatuDaru'IKutub.

NiZÂMULMULK, (2009), Siyâsetnâme, (Çev. Mehmet Taha Ayar), İstanbul: Türkiye İşbankası Yayınları.

ÖGEL, Bahaeddin, (1978), Türk Kültür Tarihine Giriş, V, Ankara: Kültür Bakanlığı. 
ÖGEL, Bahaeddin, (1993), Türk Mitolojisi, I, Ankara: TTK.

ÖZAYDIN, Abdulkerim, (1997), "Halîl b. Kalavun", TDViA,İstanbul:Türkiye Diyanet Vakfı, C. XV: s.319-320.

SEVIM, Ali (Çeviren), (1982), İbnü’l Adîm, Biyografilerle Selçuklular Tarihi İbnü’l Adîm Bugyetüttaleb fî Tarihi Haleb (Seçmeler), Ankara: TTK.

ŞEŞEN, Ramazan, (2016), Haçlılar Önünde Sultan Baybars, İstanbul:Yeditepe Yayınevi.

ŞEŞEN, Ramazan,(2004), "el-Melikü'l-Efdal, Ali”, TDViA, İstanbul: Türk Diyanet Vakfı: C. XIX: s. 62-63.

TURAN Osman, (1969), Selçuklular Tarihi ve Türk-İslâm Medeniyeti, İstanbul: Turan Neşriyat Yurdu.

TURAN, Osman, (1973), Doğu Anadolu Türk Devletleri Tarihi, İstanbul:Turan Neşriyat Yurdu.

TURAN, Osman, (1958), Türkiye Selçukluları Hakkında Resmî Vesikalar, Ankara: TTK.

USÂME İBN MUNKIZ (2006), Kitâbu'litibâr, İbnMunkız Haçlılara Karşı, Çev. Selahattin Hacıoğlu, İstanbul: Bordo Siyah Yayınları.

YAKUT ,(1977), Mucemu’I Buldan, III, Beyrut: Daru Sâdır.

ZENGIN, Murat, (2018a) “Melikü’n-nâsırŞihâbuddinAhmed ve Melikü's-sâlihlsmâil Dönemlerinde Memlûk Türk Devleti: İki Kardeş Tek Devlet (19 Mart 1342-4 Ağustos 1345)", TAD, C. $37 /$ S. 64: s. 227-260.

ZENGIN, Murat, (2018b), “Melikü'l-MansûrEbîBekr b. Muhammed Dönemi Memlûk Türk Devleti Tarihi (Elli Dokuz Günlük Saltanat)", HistoryStudies, Volume 10 Issue 3: p. 257-270. 